\title{
Investigating the effect of corneal Herpes Simplex Virus-1 infection on Toll-Like Receptor expression in human peripheral blood mononuclear cells
}

\author{
T Chan ${ }^{*}$, B Coffey, D Shahnazaryan, C Jefferies, C Murphy \\ From International Conference for Healthcare and Medical Students 2011 \\ Dublin, Ireland. 4-5 November 2011
}

\section{Introduction}

Herpes Simplex keratitis (HSK), caused by Herpes Simplex Virus type 1 (HSV-1), is the leading cause of infectious corneal blindness in the western world [1]. Initial infection develops through ocular surface entry from droplet spread [2]. Once HSV-1 has breached the epithelial barrier of the ocular surface, it is recognized by Toll-Like Receptors (TLRs), which then activate the appropriate innate immune response. Despite the high prevalence of HSV-1, only a small minority of patients develop ocular manifestations. Therefore, we hypothesized that TLR expression and activity may be deregulated in patients with HSK, which would reflect in peripheral blood mononuclear cell (PBMC) responses observed in these patients. We investigated the effects of the TLR ligands 3, 4, 7 and 9 (as they are involved in anti-viral immune defence [3]) on cytokine induction from a patient with active HSK and compared responses of this patient to TLR ligands on a subsequent follow up visit where disease was diagnosed to be inactive.

\section{Methods}

PBMCs were isolated with Ficoll-Paque Plus density gradient centrifugation. Cells were stimulated with ligands to TLRs 3, 4, 7 and 9 - polyinosinic: polycytidylic acid (poly I:C), lipopolysaccharide (LPS), imiquimod (IMIQ), and CpG A, B, and C, respectively, for 4 hrs and overnight. Following stimulation, supernatant was removed for measurements of TNF- $\alpha$ and IL-6, which were determined by enzyme-linked immunosorbant assay (ELISA). mRNA was extracted from stimulated cells using the Trizol method and changes in levels of TLR expression were quantified by qPCR.

\section{Results}

The overall qPCR result showed that during the active phase of HSK the patient analysed in this study had higher TLR expression than when disease had resolved. In the active patient, TLR 4 expression was particularly high when stimulated with poly I:C, IMIQ and CpG C. TLR 3 and 7 showed a moderate increase when stimulated with LPS and poly I:C, whereas TLR 9 expression remained low throughout. Differences in IL- 6 and TNF- $\alpha$ production were also observed when samples similarly stimulated were analysed.

\section{Conclusions}

In the active patient, the increased TLR expression correlates with the increased levels of cytokines TNF- $\alpha$ and IL-6 in the ELISAs. This means that the entire TLR signalling pathway is functioning at a higher level when the patient is actively infected with HSV-1.

\section{Acknowledgments \\ Alumni Student Research Fund in Vision Research generously supported by Dr Bobby Braunstein.}

Published: 9 July 2012

\section{References}

1. Young RC, Hodge DO, Liesegang TJ, Baratz KH: Incidence, recurrence, and outcomes of Herpes Simplex Virus eye disease in Olmsted County, Minnesota, 1976-2007. Arch Ophthalmol 2010, 128(9):1178-1183.

2. Kaye S, Choudhary Anshoo: Herpes Simplex Keratitis. Prog Retin Eye Res 2006, 25(4):355-380.

3. Kawai T, Akira S: TLR signaling. Cell Death Differ 2006, 13:816-825.

\section{doi:10.1186/1753-6561-6-S4-P38}

Cite this article as: Chan et al: Investigating the effect of corneal

Herpes Simplex Virus-1 infection on Toll-Like Receptor expression in

human peripheral blood mononuclear cells. BMC Proceedings 2012 6(Suppl 4):P38.

* Correspondence: tysonchan@rcsi.ie

Royal College of Surgeons in Ireland, Ireland

(0) 2012 Chan et al; licensee BioMed Central Ltd. This is an Open Access article distributed under the terms of the Creative Commons Attribution License (http://creativecommons.org/licenses/by/2.0), which permits unrestricted use, distribution, and reproduction in any medium, provided the original work is properly cited. 